\title{
The Immigrant and America: Assimilation of a German Family* Part I
}

C. Carnahan Goetsch

THE STRUGGLE OF IMMIGRANT CHILDREN for assimilation into American society deserves more documentation than it has received. The history of their experiences reflects larger forces and trends present in American life during the late nineteenth and early twentieth centuries. This article traces the assimilation of Marx Goettsch's children after his immigration to the Davenport, lowa area in 1871. Due to their education in various scholarly and professional fields, the assimilation of the Goettsch brothers appears dramatically swift, but in fact they proved to be in some respects unmeltable. It will be seen that the combined circumstances of their German heritage, lowa home, and peculiar exposure to the American dream made possible their advanced educations and influenced their subsequent assimilation into American society.

Marx Goettsch was born in Bentfeld, near the city of Kiel in Schleswig-Holstein on Nov. 10, 1844. Kiel is in northern Germany, south and east of Denmark. The small state's location caused a series of wars and bitter disputes between the Danes and Germans over the possession of the land, creating a situation similiar to the FrancoGerman conflict over Alsace-Lorraine. Marx was the only child of a peasant family, and his youth was no different than that of any other boy born to poor farming parents.

In 1868 , due to the policy of involuntary conscription existent

*I would like to express my gratitude to Drs. Marianne Goettsch, Elvira Goettsch, Erna Goettsch, Arthur Goetsch, and John Goetsch for their cooperation in providing information for the compilation of this study. 1 would also like to thank Prof. John Gable of the Brown University History Dept. for his encouragement and advice. 
in Germany at the time, Marx was called into the Prussian Army at the age of twenty-four. He remained a private throughout his military experience, and while serving in the army during the years 1868-70, he was trained in the trade of leather-working, and, in particular, the craft of shoemaking. He gained a considerable amount of skill and excellence in this trade, the practice of which was to be the major source of his income for the rest of his life.

At the outbreak of the Franco-Prussian War in 1870, Marx, already in the army, was immediately sent off to the front. He remained at the front throughout the course of the relatively short, but bloody, war, winning several decorations, including the cherished Iron Cross. The respect for discipline, honesty, and hard work which Marx acquired from his military experience remained with him for the rest of his life.

Marx was married in 1869 to Miss Anna Heur, a native of his hometown of Bentfeld. By the end of the war and his discharge in 1871, Anna had given birth to a son named Henry. Upon returning to his native town, Marx found little opportunity for the employment of his shoemaking skills in the postwar economic depression. The immediate responsibilities of supporting a young family no doubt amplified the economic disappointments which Marx experienced at this critical point in his life. Fortunately he had returned home from the army with a comfortable amount of savings from his pay, but Marx was soon confronted with the choice of staying at Bentfeld and depleting his capital during a period of economic. stagnation or of emigrating to America and employing his capital in establishing himself a homestead and business there. His decision was a quick and firm one in favor of emigration.

The anxiety of Marx's decision was lessened by the presence of a large contingent of Germans from Schleswig-Holstein in the Middle West and particularly in the Davenport, lowa and Moline, Illinois areas. The letters of these earlier emigrants describing the conditions for advancement rendered the picture of America less foreign and more accessible. There were also American steamship company agents who painted glowing pictures of American life, as well as agencies from individual states such as lowa, Illinois, and Michigan circulating literature aimed at attracting immigrants. Detailed advice and instructions were available to the prospective immigrant from religious and socially-minded sources such as the German pastor $F$. W. Bogan, who wrote an article entitled 'Instructions For German 
Immigrants' which warned against planless and lazy intentions and the flagrant swindlers who preyed upon the newly arrived immigrants in New York City. The pastor emphasized that:

It is of the highest importance for every immigrant, and the very means of his livelihood, going hand and hand with the study of the English language, that he finds as soon as possible, an occupation adapted to his powers and abilities. Labor is a principle condition of his happiness .... 1

In 1871, Marx Goettsch, was in an excellent position to emigrate-young and unfettered with property or business connections, he possessed a trade and the necessary capital for homesteading. As a veteran who had witnessed the destruction of life and the disruption of society resulting from war, Marx felt attracted to America because it appeared to be a nation. which had settled its major internal conflicts and had begun developing its vast natural resources in a land with no threatening enemies. So he bid his kin goodbye and crossed the Atlantic in a steamer with his wife Anna and son Henry. Upon arriving in New York Harbor, they were rapidly processed through Castle Garden (the predecessor to Ellis Island) since they had already determined their destination. Marx and his family were soon able to board one of the frequent immigrant trains which ran west to Chicago and beyond into the Middle West.

Marx's choice of Moline, Illinois turned out to be a profitable one. He found employment in the leather shop of a Swede who, in Marx's opinion, mistreated him with a harsh and unfair attitude he directed toward all his employees. The resulting personality conflict eventually ended when Marx left two years later, but for the rest of his life Marx would miss no chance to curse that Swede. These first two years were important in that they gave Marx and Anna an opportunity to become acclimated to the taste and form of life in America.

After conferring with some of his acquaintances in Moline as to the layout of the surrounding territory and the possibilities for purchasing land, Marx decided to move across the Mississippi River and settle in Davenport, lowa. In 1874 he purchased a block-long, hundred-foot deep plot of property facing West Locust Street on the

\footnotetext{
'. R. W. Bogan in The Germans in America, quoted by Rhoda Hoff, America's Immigrants (Henry Z. Walck Inc., New York, 1967), p. 62-63.
} 
then outskirts of the city. This plot was situated on the crest of the gradual incline which begins at the bank of the Mississippi and slopes up through the city, and consequently afforded a good view of downtown Davenport and the river beyond. At that time this location, later addressed as 1602 West Locust Street, was on the fringe of Davenport's development, with open farmland immediately accessible to the west.

Marx promptly began constructing a moderately large house intended to function as both shoemaking shop and home for his growing family. Eventually there were to be five sons-Henry (born in Germany in 1870), Charles (born in 1875), Julius (born in 1876), Emil (born in 1883), and Arthur (born in 1886)-and one daughter, Minnie, born in 1873, in the household. Marx proceeded to build, over a period of several years, four more houses on his land.

Davenport is situated directly on the shore of the Mississippi River facing the island of Rock Island and the city of that name beyond it in Illinois. Surrounding the low, level plain on which the city of Davenport is built is some of the most rich and fertile farmland in the state of lowa. In the early days of Davenport, the wealthy citizens of St. Louis took advantage of the area's picturesque and accessible setting by traveling there for vacations. As the years went by, more immigrants and settlers established farms and homes in the surrounding countryside: when the first official census was taken in 1847 there were 3,652 citizens, in 1863 there were 26,277 , and by 1875 there was a population of $39,736 .^{2}$ By the end of the 1860 s, Davenport was a going concern, a minor but growing urban center, eager to foster the steady boom which had swelled its population and productivity. Beginning at this time and continuing into the twentieth century, it was the conscious intention of the city's government and constituents to strive for a rank of status equal to that of the great cities of the upper Mississippi Valley-St. Paul, Minneapolis, and St. Louis.

Davenport, like many other young and growing cities in the Gilded Age, expressed its ebullient and prosperous mood in its energetic celebrations of national and ethnic holidays. Davenport was noted for its high percentage of German and Scandinavian citizens from Schleswig-Holstein and lower Denmark. The result

${ }^{2}$ Harry E. Downer, History of Davenport and Scott County lowa, Vol. 1 (S. J. Clarke Publishing Co., Chicago, 1910), pgs. 567-568. 
was a curious ritual, developed over the years, in which the Danes would observe a long-distant victory over the Germans in SchleswigHolstein by staging a parade through Davenport which ended in a picnic in the central park. The Germans would line the streets on this occasion and do their best to disrupt the pomp and ceremony with jeers, laughter, and the usual friendly insults. When the Germans staged their parade and picnic celebrating one of Germany's victories over Denmark, however, the roles were naturally reversed. The newly Americanized immigrants rarely missed any festive occasion, and many observers have noted that oftentimes the German-Americans celebrated Independence Day with more vigor and show than did the native-born Americans. Even into the first decade of the twentieth century, when old age might have been a just excuse for Marx Goettsch, he always turned out for a parade in observance of the Prussian Army's victory over the French in the Franco-Prussian War with his Iron Cross and other decorations pinned across his chest.

But at the root of this atmosphere of prosperity and celebration was the blunt reality of hard, unrelenting work. Yoked with the Gilded Age's tendency to invent new methods of flaunting its wealth was its dogged determination to accumulate as much of that wealth, and in any manner, as was possible. Marx Goettsch, who found himself only one of 160 shoemakers in Davenport, ${ }^{3}$ was able to support an ever growing family primarily through the maintenance of a reputation among the local shoe dealers and customers as an excellent and reliable shoemaker. It was here that his training in the Prussian habits of meticulous craftsmanship and lengthy working hours was most valuable. Marx's shoemaking shop was under the same roof as his home, and it was not unusual for him to work both day and evenings when necessary. His most expensive pair of shoes sold for four dollars, a price which his wife Anna objected to as being too high. If a customer approached Marx directly for a pair of shoes and happened to choose a pair which Marx believed to be the wrong fit, he would refuse to sell the shoes. The most expensive product he made was custom-fitted riding boots; these he sold for twenty-five dollars to the wealthier farmers in the area.

Marx did have additional sources of income. For a rent of six dollars a month each, he let out the four other houses on his

${ }^{9} /$ bid., p. 736. 
property to other families. Keeping canaries was a hobby which grew into a minor source of income since he could sell a young songbird for five dollars. He did not advertise, however, but sold the birds mainly through word of mouth.

Marx's frugality made an early impression on his children. One of the few opportunities open to the young Goettsch boys for part-time labor was working in the farms around Davenport topping onions for two cents a bushel. The children would cut off the bud of the onions to keep them from flowering and collect the toppings in a basket. They would return home with ten cents on a good day, and, since Marx believed that was too much money for any child to have, he took a nickel and let his sons keep a nickel. The big day of the year for the Goettsch boys was July $4 \mathrm{th}$. Their father gave each of them one-half of a bunch of firecrackers which cost ten cents a bunch. One year the price was reduced to a nickel a bunch and each boy dreamed of getting a whole bunch for himself. But, when the big day arrived, each boy received the usual allotment of one-half bunch. By maintaining such an economical attitude, Marx was eventually able to lend money to his younger sons for their college and graduate studies. From the time he first began earning money in America until his death in 1914, Marx was always able to feed, clothe, and support his family. He left in his will a surprisingly substantial sum to be divided among his children.

The political views of Marx Goettsch have been described by his only living son, Arthur, as "rabid." He was a rabid Democrat. The extent of his political polarization seems to reflect the reaction of many immigrants to the established Republican Party. It is evident that he was strongly influenced early in the 1870 s during his initial experiences in America (perhaps by the corruption of Grant's administration), and he remained faithful to the Democratic Party throughout his life. Marx's best and closest friend was a man named Wichelmann, a veteran of the Civil War and consequently a devoted Republican. Arthur Goetsch recalls many occasions ${ }^{4}$ when these two men would be engaged in relaxed conversation of the friendliest kind which would suddenly be transformed into a vehement and bitter argument at the mention of any controversial political topic. One subject which never failed to bring the men close to blows was the relative merits and faults of the Republican presidents and of their

${ }^{4}$ Arthur Goetsch, 'Four Hour Taped Interview' (Fort Lee, New Jersey, $1.971)$. 
policy of handing out liberal pensions to all Civil War veterans of the Union Army. Wichelmann was obviously in favor of such governmental action, whereas Marx was of a markedly different opinion.

As a young boy back in his native town of Bentfeld, Marx had performed the usual functions of altar boy in the local Lutheran Church. By the time he was inducted into the army, he was not influenced by any established church nor did he profess himself to be a Freethinker or religious radical. At the time of his immigration to Davenport, there was no German Lutheran Church available which he and his wife might have attended, and so by dint of circumstances he dropped away from the church. The result was that his six children did not receive any formal religion or Sunday school education, and were not inducted into any church. His children grew up in an atmosphere of religious tolerance which arose from their father's attitude that "If somebody believes in God and has faith in a church and finds comfort from it, that's fine, it's his business and I won't make light of it-l just wouldn't do it myself, that's all." ${ }^{\prime 5}$ and which influenced their feelings toward religion throughout their lives.

The Goettsch children grew up in a home environment where absolute respect for the authority of their father was the rule. Marx was a stern and imposing figure of a man with a long white beard, and he could execute his disciplinary commands with great effect. If he set the curfew for ten o'clock, he would step outside at 9:55 and call out "Jungst! Jungst!" and his sons would stop playing and return home without comment. There was never any thought of complaining, as Arthur recalls, and to show disrespect was simply out of the question. But never were the children slavishly or unjustly treated. Arthur remembers his family as being tightly knit and very warm to one another, with never any serious dischord or fracturing influences. The great leavening factor between the children and their father was Anna, their mother. She was the first person they went to with any plans or everyday problems. Oftentimes Anna and the children would combine forces to get around the habits or inclinations of Marx. One incident may serve as an illustration.

Marx had the distinctively German habit of smoking his tobacco in a long wooden pipe which extended down to the waist and curved up into a bowl. He enjoyed this custom to such an extent that one pipe after another would soon begin to reek with accumulated tar ${ }^{s}$ lbid. 
and resin and drive Anna and the children to desperation. When an opportune moment presented itself, Anna would notify the children and the pipe would be conveniently mislaid. Sooner or later Marx would emerge from his workshop looking for the pipe, and the children would conscientiously assist him in the search for it. If Marx did not seem too extremely put out and returned muttering to his shop, Anna and the kids would throw the pipe in the fire and be done with it. As often as not, however, his Prussian temper would flare up, causing Anna to give one of the children the high sign, after which the pipe would be duly uncovered and returned to the placated Marx.

Marx and Anna were fair in their treatment of the children, and always provided them with the essentials. Among the children there was a strong bond of comradeship and an eagerness to assist and to share one another's knowledge and talents. By the time his sons reached high school, Marx thought he could trust them to make their own decisions, and as it turned out, this trust was a necessary one.

All of the six children completed the usual elementary grades offered by the local public school, and all of them except Minnie went on to attend the high school in Davenport. While it was not unusual for a child to go through elementary school, it was exceptional for a boy to attend high school since higher education was not popular at the time. Most parents believed that their child's time could more profitably be spent back home on the farm or at the grocery. For a girl to go on to high school was extremely rare except for the wealthier families. Even so, women who did go beyond the elementary grades usually attended music or finishing schools.

To illustrate the extraordinary low, by modern standards, percentage of elementary school children who went to high school, the experience of Arthur Goettsch is a case in point. Of the eighty-five children who graduated in Arthur's elementary school class, only two went on to high school-Arthur himself and his close neighbor, the son of a grocer. These two boys attended the main high school in Davenport with the students from the other local districts, where they encountered a strictly organized regimen of study in such subjects as English, German, Latin, history, mathematics, chemistry, Greek in the senior year if desired, and such extracurricular activities as playing in the school band (all the 
brothers played either cello, clarinet, or flute) and sports. Arthur maintained, as did his four older brothers, an above average level of performance, and by the time he was about to graduate in 1903, he had already chosen a college-the University of Chicago.

The relative ease and assurance with which Arthur chose to attend college after high school is a reflection upon the efforts by which his four brothers surmounted the usual obstacles standing between a poor immigrant son and a college education: family and money.

The fact that the Goettsch boys worked hard in school and consistently achieved above average grades was a source of pride for Marx and his wife. But it was at first just that-a feeling of satisfaction that their sons were proving themselves capable in their chief endeavour-and there was no doubt in Marx's mind that his sons would cease their education after elementary school and set about learning a practical trade. When Henry's teachers urged Marx to allow Henry to continue his studies on into high school, it was this pride and the feeling that such a successful student should go on with his education which finally overruled Marx's concern for his son's future.

But it was not as easy for Marx to comprehend why Henry wanted to go on to college at the University of lowa after his graduation from high school. Marx did not understand why any able-bodied young man would want to waste away the best years of his life learning an intellectual subject when he could start right in as a shoemaker, factory worker, business man, or learn some other practical means of livelihood which would begin paying off immediately and offer chances for advancement. Marx was not an anti-intellectual. His pessimism arose from a practical concern for his son's future. He simply found it hard to believe Henry could actually pursue an academic career which would have been closed to him had he lived in Germany. This was the attitude which Henry, the real pathfinder of the brothers, had to overcome. With the sympathetic support of his mother Anna, who believed in her son's right to pursue his own goals, Henry was able to explain to Marx that college was a long-term investment which, if managed correctly, eventually paid for itself many times over.

It is appropriate here to include some details of Henry's early life, for even as a young boy Henry's inquisitive and determined nature began to shape his relationship with his father as advisor and 
friend. One winter day when Henry was fourteen years old, he spied in the window of a book store a very old encyclopedia that was selling for ten dollars. He had only five dollars, saved from his summer's work in the onion fields. Marx discouraged the purchase of English books because he could not read English, but after listening to Henry's arguments he relented and gave his son the extra money. Henry carried the books home on his sled, a few large volumes at a time, and proceeded to read them from A to $Z$. In later life he often amused his children with odd bits of information remembered from those days.

Henry was taught how to play chess by his father, but no matter how hard the boy tried he could never win. It was Marx's habit to buy inexpensive paperback books from a bookseller in Germany, and it was his son's responsibility to make out the orders from the catalogue. One day Henry noticed that there was a book on chess playing. Without saying anything to his father, he included the title in the next order, paying for it with his own money. When the shipment arrived from Germany, Henry opened it and hid the chess book. He studied it on his own and learned why his father was winning. From that time on, he began to win. Marx became so inquisitive that Henry finally confessed and the two studied the book together.

During the first fifteen years before the birth of Arthur and on into the succeeding years, Marx Goettsch leaned heavily on Henry to interpret the perplexities of the new culture. The decisions which Henry made and the methods which he employed to ultimately earn a Ph.D. cleared the way for his brothers to follow similar pursuits.

Henry graduated from high school at the age of seventeen as valedictorian of his class. A young man who wanted a college education in Davenport before the turn of the century usually chose the University of lowa since it was only fifty miles away and was cheaper for residents than any other institution. Family finances, however, did not permit Henry to go on to college as he wished, and so he chose to teach in a one-room country school. After nine years in the community he became principal of a four-room, small town school. During this period he learned to play the violin, and he organized a quartet after teaching three others to play stringed instruments. This quartet provided music for parties, and Henry also assembled an eight piece band that was in demand for large dances. Henry organized a Turn-Verein (German gymnastic society) and 
acted as town clerk as well. Some of these activities provided income. He married in 1894 and over the years three children were born. Food for the family was grown in his garden and he experimented with new crops and fertilizers. One summer he took a teacher's course in chemistry at Cornell.

By the time Henry was 26, he and his wife had saved up sufficient funds to allow him to enter the State University of lowa at lowa City. The only money not earned by Henry for his higher education was a modest sum contributed by his father-in-law. During his teaching years he had never stopped reading and studying, and since he was permitted to obtain course credit by passing examinations, Henry won his B.A. in two years. In another year he had his M.A. in Chemistry. He was a member of the chess team and one of the group which simultaneously played the famous Pillsbury while he was blind-folded (Henry's brother Julius was also one of this group).

After graduation, Henry took an Instructorship at the Michigan College of Mines in Houghton for two years in order to earn some money. The following three years were spent at the University of Chicago obtaining his doctorate in Chemistry. He proceeded to work for two years at the Mallinckrodt Chemical Works in St. Louis as a Research Chemist, and then accepted an Assistant Professorship at the University of Cincinnati, where he devoted himself to teaching. He retired as Professor Emeritus thirty-one years later. His avocations included music, the study of government, photography, hiking, canoeing, rose culture, and wine making. He had a large library and a fine collection of music records. He enjoyed giving papers in German before the German Literary Society.

This is the pattern which remained essentially the same for each of the five brothers: because of their high grades and fluency with the cello, clarinet, or flute, the boys received partial scholarships to the college of their choice, which they supplemented after marriage and during graduate studies by teaching public school whenever necessary. However, by the time the two younger sons (Emil and Arthur) graduated from high school with the intention of studying medicine, the improvement in family resources permitted them relatively consistent financial support.

A second, and final, installment of this intriguing study of an immigrant German family will appear in the next issue (Fall 1973, Volume 42, Number 2). 
Copyright of Annals of Iowa is the property of State of Iowa, by \& through the State Historical Society of Iowa and its content may not be copied or emailed to multiple sites or posted to a listserv without the copyright holder's express written permission. However, users may print, download, or email articles for individual use. 